\title{
ARISTOTLE'S DEFINITION OF ANAGNORISIS
}

\author{
JOHN MACFARLANE
}

IN CHAPTER 11 of his Poetics Aristotle defines recognition (ảvarvẃ@l-

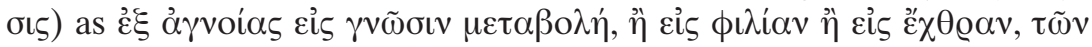

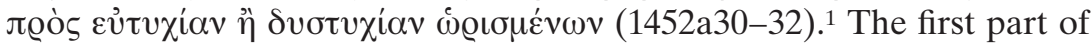
the definition characterizes recognition as a change from ignorance into knowledge, leading to either friendship or enmity. ${ }^{2}$ But what is added

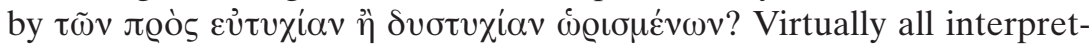
ers take this phrase to be a subjective genitive characterizing the persons involved in the recognition. On the prospective construal, it characterizes them by reference to their future states, as "the persons destined or marked out for good or bad fortune"; on the retrospective construal, it characterizes them by reference to their past states, as "the persons who have [previously] been defined by good or bad fortune."3

In what follows I question the assumption common to both these construals: that the genitive phrase characterizes the persons or characters involved in the recognition. On the basis of a survey of Aristotle's

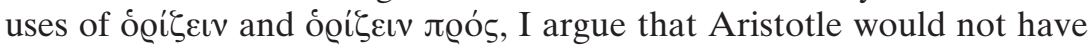

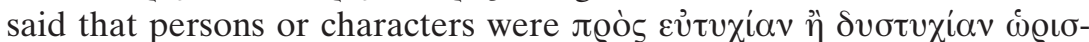
$\mu \varepsilon \dot{v} \omega v$. A satisfactory construal of the genitive phrase, I suggest, depends on a correct understanding of its syntax. The interpretation I recommend, which takes the phrase as a partitive genitive, allows us to

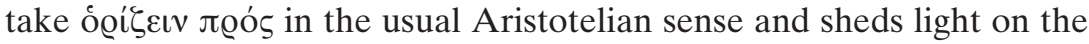
relationship between recognition and reversal.

${ }^{1}$ I here relied on Kassel's 1965 OCT, except where indicated. All translations from the Poetics are my own.

${ }^{2}$ For a discussion of the interpretative problems here see Belfiore 1992, 154-60.

${ }^{3}$ The prospective construal can be found in Bywater 1909, Butcher 1911, Vahlen 1914, Phillipart 1925, Fyfe 1927, Rostagni 1945, Cooper 1947, Grube 1958, Warrington 1963, Kamerbeek 1965, Potts 1968, Golden and Hardison 1968, Hubbard 1972, DupontRoc and Lallot 1980, and Heath 1996. For the retrospective construal see Else 1957 and 1967, Janko 1987, and Belfiore 1992. 


\section{CRITICISM OF EXISTING INTERPRETATIONS}

Else (1957) deserves credit for showing what is wrong with the prospec-

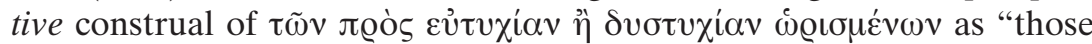
who have been destined for good or bad fortune." The problem is not just that the notion of destiny is foreign to both Aristotle's poetics and his metaphysics (351). That problem could be avoided by understanding "destined" as "destined by the poet." 4 The decisive argument against the prospective interpretation is rather that "... in Aristotle's language wolouḱvos does not mean 'destined' or 'marked,' but 'defined,' 'delimited" " (351).

About this Else is absolutely right. Although the tragic poets

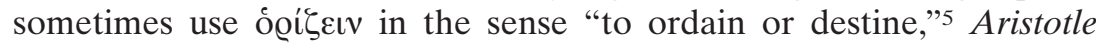
does not seem to use it in this way. In nearly two full columns of references to forms of ógígıv in Aristotle, the only one Bonitz (1870) glosses as "destine" is the one that is now in dispute: ஸ́@ı $\mu \dot{\varepsilon} v \omega v$ in the

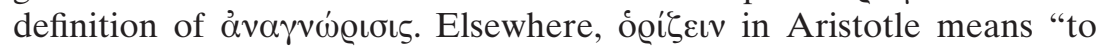
define, determine, or mark out as distinct from other things." 6 For

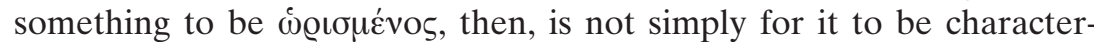
ized, but for it to be characterized in a way that distinguishes it from other things and sets it apart as the thing or kind of thing it is.

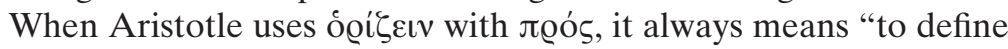
or determine by reference to some standard."' Hard and soft are de-

${ }^{4}$ See Butcher 1911 and Dupont-Roc and Lallot 1980 (with the note on 233). Else (1957) objects (citing 14.1453b22-26) that tragic poets were not able to determine whether their characters met with good fortune or bad: in this respect, they were bound by the traditional story (351). But as Mae Smethurst has pointed out to me, the tragic poet can go as far as to have Iphigeneia sacrificed or not, to place Helen in Troy or elsewhere, to have Medea kill her children or not.

${ }^{5}$ See A., Choe. 927 and Eur., Ant. fr. 218 Nauck. In the latter fragment, which is often cited as support for the prospective construal of Aristotle's definition, óoí $\zeta \varepsilon v v$ is used

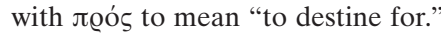

6"To define": Poet. 10.1452a15, De Part. An. 1.4.644b9, Eth. Nic. 1107a1, Rhet 1.13.1373b19, Rhet. 1.5.1361b35, Meteor. 4.4.382a19, Metaph. 5.11.1018b11, Rhet. 1.13.1373b5. "To determine or mark out": Metaph. 3.5.1002a6, Metaph. 7.3.1029a22, De Cael. 1.1.268b7, Phys. 4.13.222a25. The passive ஸ́øı $\mu \varepsilon \dot{v}$ os can mean "definite" (i.e., having been determined or marked out from others): person, Rhet. 1.13.1373b21; number, Metaph. 5.15.1020b33, 12.8.1073b13; office, Pol. 3.1.1275b15; potentiality, Metaph. 9.8.1049b6.

${ }^{7}$ I make this claim on the basis of a computer search of the entire Aristotelian cor-

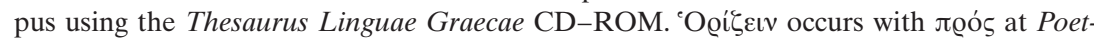


fined by reference to ( $\left.\pi \varrho \varsigma_{\varsigma}\right)$ the faculty of touch; that is, touch is the standard by reference to which something is called hard or soft (Meteor. 4.4.382a19). Just and unjust actions are defined by reference to particular and universal law; that is, we look to the law in determining whether an action is just or unjust (Rhet. 1.13.1373b2). The genera of animals (birds, fishes, etc.) have been defined by reference to similarities in the shape of organs and the whole body (De Part. An. 1.4.644b9). In each case the object of the preposition $\pi \varrho o$ s is the feature or standard by reference to which the object of ógíglv is defined.

This evidence does not, of course, preclude construing $\omega \varrho \iota \sigma u \varepsilon ́ v \omega v$

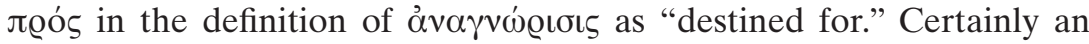
author might use a word only once in a particular sense. But we ought

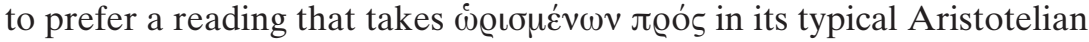
sense of "defined by reference to," if such a reading can be found.

Is Else's retrospective construal such a reading? As Else reads it,

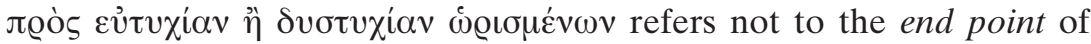
the tragic change, but to the beginning: "not the idea that Oedipus is 'destined' to be unhappy, but the simple fact that at the beginning of the play he has a determinate status with respect to 'happiness': that is, that he enters upon the action a happy man" (351). The function of $\tau \tilde{\omega} v$

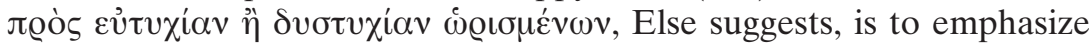
that "the measure of what is accomplished by the recognition, for weal or woe, is the status from which the hero began" (352). ${ }^{8}$ Thus

[Recognition is] a shift from ignorance to awareness, pointing either to a state of close natural ties (blood relationship) or to one of enmity, on the part of those persons who have been in a clearly marked status with respect to prosperity or misfortune. ${ }^{9}$

(343, emphasis mine)

ics 10.1452a31, Meteor. 4.4.382a19, Rhet. 1.13.1373b2, De Caelo 1.1.268b7 and 1.11.281a11; Metaph. 5.11.1018b11, De Part. An. 1.4.644b9; Phys. 4.13.222a25. At Metaph. 5.15.1020b33,

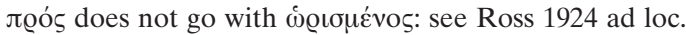

${ }^{8}$ In support of Else's proposal Janko (1987) notes (ad loc.) that it is Oedipus' rec-

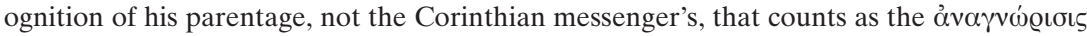
in Oedipus Tyrannus. According to Janko, recognition by minor characters "does not matter because we are not concerned with their happiness." But what about the swine-

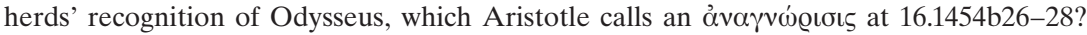
${ }^{9}$ Else's 1967 translation reads: “. . . of people who have previously been in a clearly marked state of happiness or unhappiness." 
But this translation does not meet the mark Else has set for himself. To

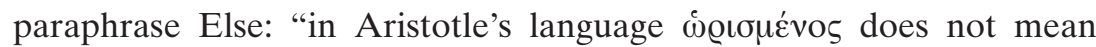
'having been in a clearly marked status,' but 'defined,' 'delimited.' " To be in a "clearly marked status with respect to prosperity or misfortune" is not to be defined by prosperity or misfortune, but to have prosperity or misfortune as an evident attribute. ${ }^{10}$ Thus the reasons Else has given for rejecting the prospective construal seem to cut equally against his own interpretation.

Why does Else ignore his own advice? The reason, I suggest, is that he does not see any alternative to taking the genitive phrase to characterize persons or characters, and he sees that neither persons nor characters can be defined by reference to their good or ill fortune. ${ }^{11} \mathrm{~A}$ person's prosperity or misfortune, no matter how "clearly marked," cannot be part of what it is to be that person: if it were, the person could not suffer a change of fortune without becoming someone else. In fact, on Aristotle's view, concrete individuals (like particular persons) cannot be defined at all (cf. Metaph. 7.10.1036a2-6, 7.15.1039b27-29), since "definition is of the universal and the form" (Metaph. 7.11.1036a28-29). One can give an account of the essence of a person (7.11.1037a26-29) that is, of the person's form, the human soul (De An. 2.1) — but such an account would make reference to nothing particular to the individual, let alone the individual's relation to good or ill fortune. And although characters are universals, and hence definable, ${ }^{12}$ what defines them is surely not their initial good or bad fortune. What makes Oedipus the character he is, is not his initial state of prosperity but the particular way he falls from it-by unwittingly fulfilling a prophecy in trying to escape it, by becoming aware that he has wronged those dearest to him, by relentlessly pursuing an investigation that leads at last to himself,

${ }^{10}$ Although swans have "a clearly marked status" with respect to color, they are not defined or determined as what they are by reference to their color. That is why, when we find black swans in Australia, we can still recognize them as swans.

${ }^{11}$ ' $\Omega\llcorner\sigma \mu \varepsilon \dot{v} 0 \varsigma$ by itself might mean "definite" (i.e., a particular person, Rhet.

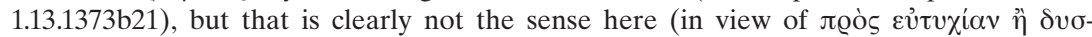

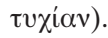

${ }^{12}$ Aristotle claims that poetry is "more philosophical" than history, on the grounds that its statements are universal, while those of history are particular (9.1451b5-7). Poetry is universal because it says "what sort of things a given sort of man will say or do, according to what is likely or necessary" (1451b8-9, emphasis added; cf. 15.1454a33-37). If poetry is to achieve this universality, its characters must be representative types. 
and so on. Neither persons nor characters, then, can be defined by reference to good or bad fortune. ${ }^{13}$

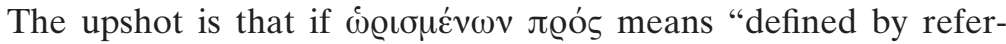
ence to," then it cannot modify persons or characters, as it is taken to do in virtually all translations and commentaries. ${ }^{14}$ Although Else recognizes the inadequacy of the traditional (prospective) construal of Aristotle's definition, he mislocates the problem: it lies not (just) in a mistranslation of $\omega \varrho \iota \sigma \mu \varepsilon \dot{v} \omega v$, but in a misconstrual of its syntax. As

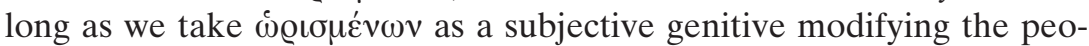
ple or characters undergoing the change, no satisfactory translation will be possible. In the next section I offer an alternative.

\section{A NEW INTERPRETATION OF THE DEFINITION}

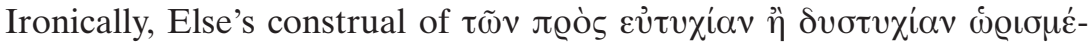

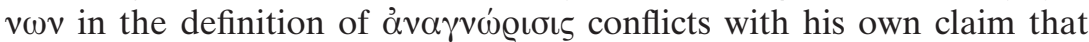
this phrase is "the exact counterpart, grammatically and in sense" (352),

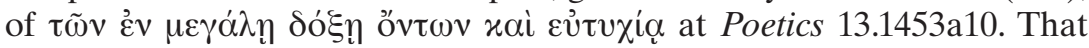
passage, in context, reads as follows:

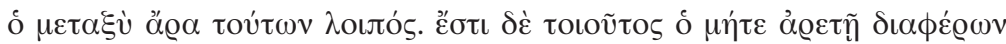

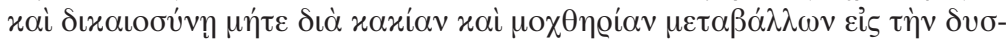

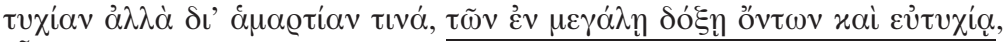

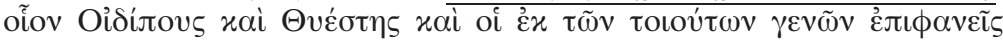

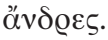

${ }^{13}$ Some proponents of the retrospective reading do what Else did not dare to do

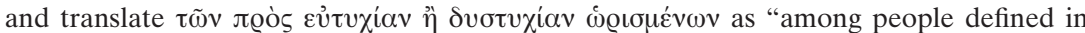
relation to good fortune or misfortune" (Janko 1987; cf. Belfiore 1992). However, since both Belfiore and Janko defer to Else to justify their translations (Belfiore, $153 \mathrm{n}$. 59; Janko, 96), it is likely that they do not intend "defined" in the literal sense, but rather something along the lines of Else's "[having] been in a clearly marked status."

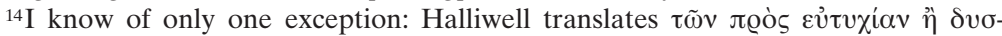

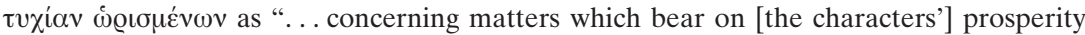
or affliction" (1987), or "... involving matters which bear on prosperity or adversity" (1995). But even if the genitive can express the loose connection Halliwell marks with "concerning" and "involving" (cf. Smyth § 1381), "bearing on" seems impossible for

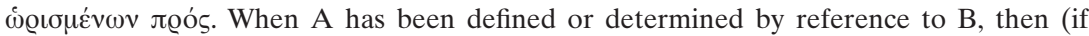
anything) it is B that "bears on" A, not the reverse. To use one of the examples mentioned above, it is the law that bears on particular just actions, not vice versa. Despite the implausibility of Halliwell's translation, however, his insight that the genitive phrase does not modify the persons or characters undergoing the recognition is a sound one. 
There remains, then, the man between these [extremes]. And such a man is the one, of those who are in great repute and good fortune, who neither excels in virtue and justice nor falls into bad fortune through vice and wickedness, but rather through some mistake-for example, Oedipus and Thyestes and the famous men from families such as this.

The emphasized phrase defines a class of men-those men who are in great repute and fortune-from which a smaller class is to be extracted, comprising only those members of the class who meet a further criterion: being distinguished in neither virtue nor vice, but falling into bad fortune through a mistake. Grammatically, the phrase is a partitive genitive, or genitive of divided whole (Smyth $\S 1306)$. Yet Else takes the "counterpart" genitive in the definition of $\alpha v \alpha \gamma v \omega$ Qı $\varsigma \varsigma$ as a subjective genitive, not a partitive genitive.

I want to suggest that Else is right about the grammatical parallel and wrong in his reading of the definition. We can make better sense of

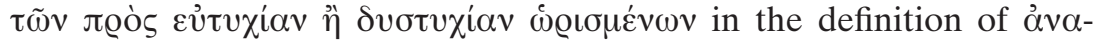
$\gamma v \omega \dot{Q} \iota \sigma \varsigma \varsigma$ if we take it as a partitive genitive specifying a larger class of changes ( $\mu \varepsilon \tau \alpha \beta o \lambda \alpha i)$ of which recognitions are to be a subset:

Recognition ... is a change, of those [changes] that have been defined by reference to good or bad fortune, from ignorance into knowledge, either into friendship or into enmity.

Because it no longer modifies persons or characters, but changes,

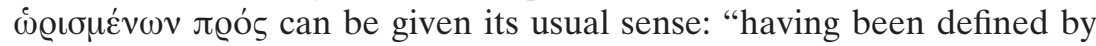
reference to." The genitive phrase picks out a class of changes that has previously been defined by reference to good or bad fortune. A recognition is a member of this class that meets a further condition: being a change from ignorance into knowledge (either into friendship or into enmity). ${ }^{15}$ Read in this way, the definition is precisely parallel to 13.1453a7-12.16

15 "Every change ( $\mu \varepsilon \tau \alpha \beta \beta \lambda \eta \dot{)}$ ) is from something into something" (Phys. 5.1.224b35225a1). Hence a natural way to define a kind of change is to specify from what and into what, just as Aristotle does here.

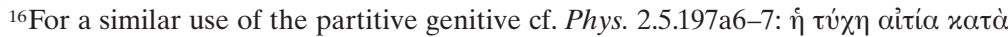

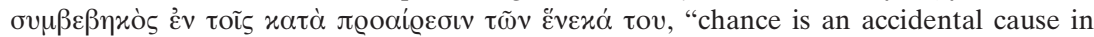
the sphere of those actions for the sake of something which involve choice" (trans.

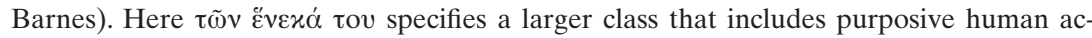

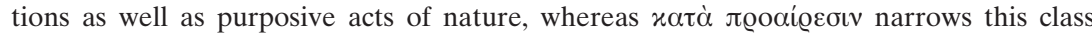
down to the class of purposive human actions. 
For the class of changes that have been defined by reference to good or bad fortune, we need look no further than the end of chapter 7:

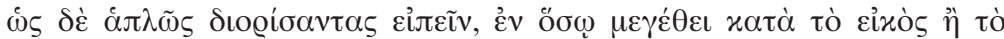

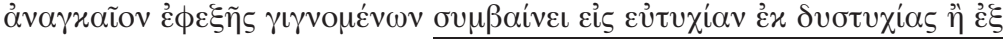

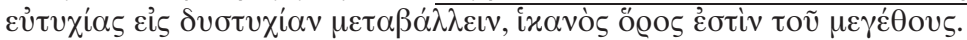

(7.1451a11-15)

And to give a simple definition, "a length in which, while things are coming about in sequence according to what is likely or necessary, a change occurs from bad fortune into good fortune or from good fortune into bad fortune," is a sufficient limit of the length [of a tragedy].

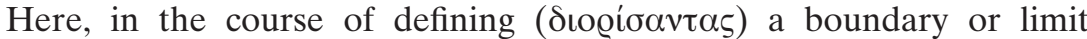
(oøos) for the length of a tragedy, Aristotle marks out the kind of change that will be part of every tragic plot: a change of fortune, from bad to good or from good to bad. That is, he defines a subclass of changes ( $\mu \varepsilon \tau \alpha \beta$ o $\lambda \alpha i$; cf. $\mu \varepsilon \tau \alpha \beta \alpha \dot{\alpha} \lambda \lambda \varepsilon เ v, 1451 \mathrm{a} 14)$ by reference to good or

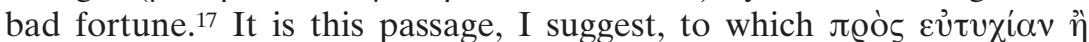

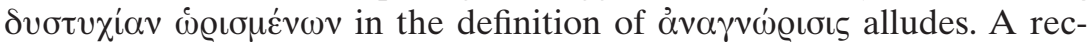
ognition is a change of the characters' fortunes that is also a change from ignorance to knowledge, leading to friendship or enmity.

\section{MULTIPLE RECOGNITIONS}

Whatever its virtues, this interpretation may appear to face a devastat-

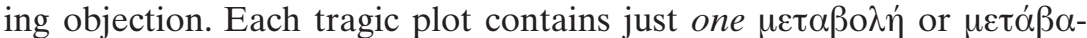
$\sigma i \varsigma^{18}$ from good to bad fortune or vice versa (otherwise 18.1455b26-29, 7.1451a11-15, and 10.1452a14-18 would be unintelligible; cf. Belfiore $1992,148)$. If recognitions are such $\mu \varepsilon \tau \alpha \beta$ o $\alpha \alpha i$, as I have argued, then it seems to follow that a tragedy can have at most one recognition. Yet Aristotle seems to allow that a tragedy might contain multiple recogni-

${ }^{17}$ Epics will also contain $\mu \varepsilon \tau \alpha \beta$ ò $\alpha i$ as defined here, though unlike tragedies they may contain more than one.

${ }^{18} \mathrm{~A}$ perusal of LSJ and Bonitz 1870 offers no basis for distinguishing between $\mu \varepsilon \tau \dot{\alpha} \beta \alpha \sigma \iota \varsigma$ and $\mu \varepsilon \tau \alpha \beta$ o $\eta_{\text {. }}$. As far as I can tell, Aristotle uses them interchangeably in the Poetics (compare 7.1451a11-15 with 18.1455b26-29). Lucas (1968 ad 1452a22) and Dupont-Roc and Lallot (1980, 230) concur. 
tions. ${ }^{19} \mathrm{He}$ claims that after Iphigeneia had been recognized by Orestes through the letter, there was need of another recognition of him by her (11.1452b3-8).

The apparent contradiction can be resolved (as so often in Aristotle) by making a distinction. When Aristotle says that there is need of "another recognition" of Orestes by Iphigeneia, all the word "another" implies is that the two recognitions are conceptually distinct. It does not preclude their being the same $\mu \varepsilon \tau \alpha \beta$ o $\lambda \eta$, and hence "one in number."20 It would be characteristic of Aristotle to say that although the recognition of Iphigeneia by Orestes is different in account $(\lambda \hat{\gamma} \gamma \omega)$ from the recognition of Orestes by Iphigeneia, it is the same in number, as "the road from Thebes to Athens and the road from Athens to Thebes are the same [road]," and teaching and learning are the same process of change (Phys. 3.3.202b10-14). The two recognitions are distinct only in the sense that they are distinct perspectives on the same tragic change of fortune.

Granted, Aristotle talks as if one of these recognitions occurs before the other, which would seem to preclude their being the same $\mu \varepsilon \tau \alpha \beta \delta \lambda \eta$. But the fact that Orestes recognizes Iphigeneia before she recognizes him does not show that the two recognitions are distinct changes of fortune. All it shows is that the audience can come to know that the change of fortune will be a change in Orestes' knowledge before coming to know that it will also be a change in Iphigeneia's knowledge.

Hence Aristotle's talk of multiple recognitions in a single tragedy is compatible with the view I have been urging: that a recognition in tragedy is the tragic change of fortune itself (insofar as it is also a change in knowledge and allegiance), not a distinct change in the characters' knowledge and allegiance, as commentators have always assumed.

${ }^{19}$ In support of this claim Belfiore 1992 cites 11.1452b3-8 and 16. 1454b26-28 (156). But the latter passage refers to recognition in epic, and Aristotle never claims that an epic can contain only one change of fortune.

${ }^{20}$ See Phys. 1.7.190a14-18, 3.3.202a18-20, 3.3.202b10-14, 8.8.262a19-21, 8.8.263b12-14; De Sensu 7. 449a16-19, De Juv. 1.467b25-27, Metaph. 5.6.1016b31-36. Admittedly, Aristotle never says that multiple recognitions in the same tragedy are conceptually distinguishable but one in number. But he does not deny that they are one in number, either. Nothing can be concluded either way from his silence on this score. 


\section{RECOGNITION AND REVERSAL}

A good test of any interpretation of an Aristotelian definition is how well it makes sense of the way Aristotle actually uses the concept defined. In this section, I use my construal of the definition of àvarvwoloıs to shed light on what Aristotle says in chapters 11 and 16 about the

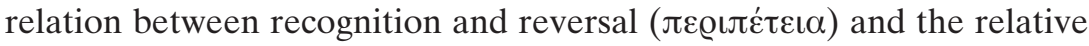
values of different kinds of recognition.

Reversal is defined as

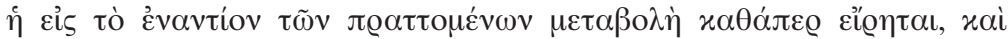

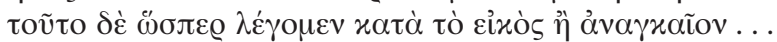

the change of the things being done into the opposite, just as has been said, and this just as we say, according to what is likely or necessary ...

Presumably a "change of the things being done into the opposite" is a change from good fortune to bad or vice versa. ${ }^{21}$ Since every tragic plot contains such a change, but not every tragic plot contains a reversal, the function of the rest of the definition must be to pick out the subclass of such changes which are reversals. Reversals, then, are the changes of fortune that take place "just as we say, according to what is likely or necessary" - that is, "from the very construction of the plot, so that these things occur as a result of the preceding actions either from necessity or according to what is likely" (10.1452a18-20).22

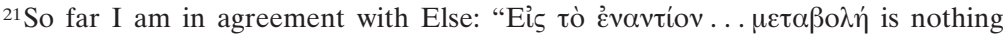

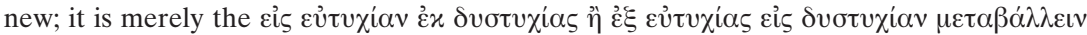

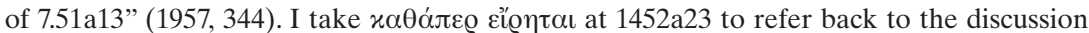
of the change of fortune at 7.1451a13-14 (see Allan 1976 for some alternatives).

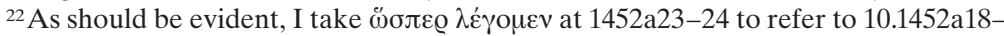
20 (see note 24 below). I hope I can be forgiven for not giving a full defense of this inter-

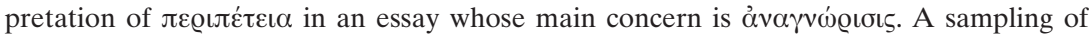
other interpretations: Bywater (1909) and Janko (1987) take $\pi \varepsilon \varrho л \varepsilon \dot{\tau \varepsilon \iota ~} \alpha$ to be an especially sudden change of fortune. Vahlen (1914) argues that it is essentially a reversal of the agent's intentions. Else (1957, 345-48) and Schrier (1980) take it to be a change in

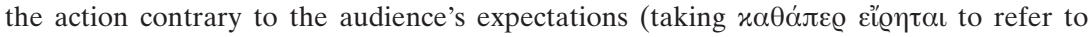
9.1452a4). Belfiore (1992) proposes that it is a discontinuous change of fortune (141-53). Halliwell (1987) takes it to be a change of fortune that occurs within the plot itself, not before the action proper. 
Like the definition of recognition, then, the definition of reversal

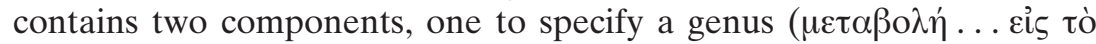
Evavtiov), the other to delineate a species or subclass within that genus

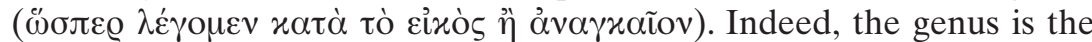
same in both cases: both recognition and reversal are changes of fortune, in the sense defined at the end of chapter $7.23 \mathrm{~A}$ change in fortune counts as a recognition when it is a change from ignorance to knowledge (leading to either friendship or enmity), as are Oedipus' downfall in Oedipus Tyrannus and Iphigeneia and Orestes' salvation in Iphigeneia in Tauris. A change of fortune is a reversal, on the other hand, when it comes about "from the very construction of the plot." 24

Of course, it can sometimes happen that the same change of fortune meets both criteria: it is a change "from ignorance to knowledge (leading to either friendship or enmity)" that comes about "from the very construction of the plot." In that case, the change of fortune will be both a reversal and a recognition. The reversal and the recognition will be conceptually distinct, but "one in number." 25 Though this odd consequence may appear to count against my interpretations of the definitions, it is actually additional support. For by allowing that a reversal and a recognition can be one in number, we can make excellent sense of the text immediately following the definitions:

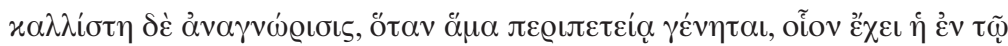

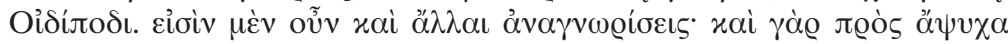

${ }^{23}$ Belfiore (1992) claims that a tragedy can contain several reversals: "although Aristotle never explicitly states this, it is suggested by his use of the plural at, for example, 24.1459b10, and by the close association between peripeteiai and recognition" (148). If Belfiore's claim were true, it would cast doubt on my claim that reversals are tragic $\mu \varepsilon \tau \alpha \beta$ o $\lambda \alpha i$, since (as we have seen) a tragedy can contain only one $\mu \varepsilon \tau \alpha \beta \beta \lambda \eta \dot{\eta}$. But Aris-

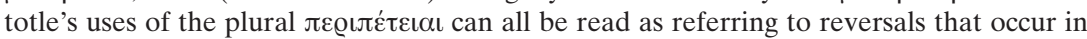
different plays. As for recognitions, see discussion above.

${ }^{24}$ Aristotle's claim at 10.1452a18-20 that both recognition and reversal should ( $\left.\delta \varepsilon \tilde{)}\right)$ come about "from the very construction of the plot" might be taken to show that coming about from the construction of the plot cannot be the distinguishing feature of reversal (see Golden and Hardison 1968, 165-66, 169). But $\delta \varepsilon \tilde{\tau}$ here expresses an aesthetic norm, not a definitional requirement (so Rostagni 1945 ad 1452a23). Aristotle's point is that a recognition should arise from the construction of the plot if it is to be good (cf. 16.1455a1618). As Else observes $(1957,341)$, Aristotle is just restating what he has already said in chapter 9: that in finer plots ( $x \alpha \lambda \lambda$ iovs, 1452a10) the tragic events should come about $\delta \mathrm{\imath}$ $\alpha 2 \lambda \lambda \eta \lambda \alpha(9.1452 \mathrm{a} 4)$.

${ }^{25}$ See note 20 above. 


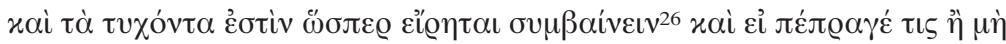

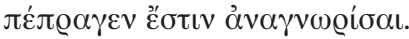

(11.1452a32-36)

But recognition is finest when it occurs at the same time as reversal, as the one in Oedipus does. There are of course other recognitions: for it is possible for [one] to occur in the way that has been described even in relation to inanimate and chance things, and it is possible to recognize whether or not someone has done [something]. ${ }^{27}$

This text poses two exegetical puzzles. The first concerns the claim that recognition is finest when it occurs at the same time as a reversal. Why should this be the case? In chapter 16 Aristotle says that the

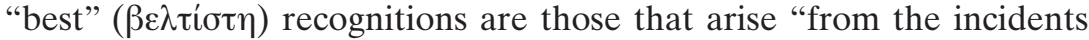
themselves, with the surprise coming about through likely means" (16.1455a16-17). It would be natural to assume that these are the same as the "finest" recognitions. But then one needs to explain the connection between a recognition's arising "from the incidents themselves" and its occurring at the same time as a reversal.

The second puzzle concerns the "other recognitions" (a34). Many commentators, guided by Aristotle's descriptions of the "other recognitions," take them to be recognitions other than recognitions of persons: that is, recognitions whose objects are inanimate things and actions (Else 1957, 353; Lucas 1968 ad loc.; Söffing 1981, 136). But given the context, "other" must mean "other than the finest recognitions," not "other than recognitions of persons." For the passage continues by contrasting the "other recognitions" with the kind of recognition just mentioned, that which occurs with a reversal:

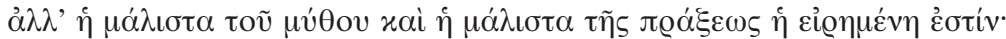

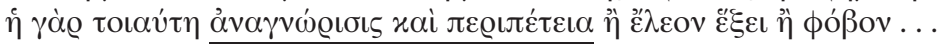

(1452a36-b1, emphasis mine)

But the one that has been mentioned is the one most proper to the plot and most proper to the action: for such a recognition and reversal will have either pity or fear...

Indeed, the definition of recognition seems to allow no room for recognitions other than recognitions of persons: recognitions must (by defi-

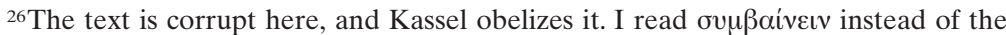

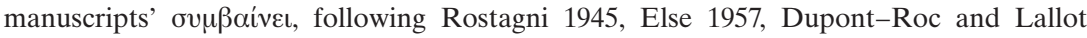
1980, Janko 1987, and an anonymous scribe (see Vahlen 1885, 148-51, for criticism).

${ }^{27}$ Bywater (1909 ad loc.) argues for a transitive reading of $\pi \dot{\pi} \pi \varrho \alpha \gamma \varepsilon$. 
nition) lead to friendship or enmity, and only persons can be friends or enemies. ${ }^{28}$ The "other recognitions," then, are not recognitions of objects and actions, but inferior recognitions of persons: recognitions other than the finest ones. ${ }^{29}$ The puzzle is to explain why Aristotle glosses these as recognitions "in relation to inanimate and chance things" and of "whether or not someone has done [something]." What kinds of recognitions does he have in mind, and why don't these occur at the same time as reversals?

I suggest that both puzzles can be solved if we take the "finest recognitions" to be those tragic changes of fortune ( $\mu \varepsilon \tau \alpha \beta \delta \lambda \alpha i$ ) that are both "from the very construction of the plot" and "from ignorance to knowledge (leading to either friendship or enmity)." On the proposed construals of the definitions, these $\mu \varepsilon \tau \alpha \beta 0 \lambda \alpha i$ will count as both recognitions and reversals. Hence the "finest" recognitions of chapter 11 are precisely the same as the "best" recognitions of chapter 16: they are recognitions that arise "from the incidents themselves, with the surprise coming about through likely means" or, equivalently, from the construction of the plot. This satisfying convergence provides some support for my construal of the definitions.

Commentators have long puzzled over Aristotle's claim that the recognition in Oedipus Tyrannus occurs at the same time as the reversal, worrying about precisely where the reversal occurs and how long it lasts (Lucas 1968 ad loc.; Else 1957, 354). What I am proposing is that in this play the recognition and the reversal, though conceptually distinct, are "one in number." They are simultaneous because they are both identical with the same $\mu \varepsilon \tau \alpha \beta 0 \lambda \eta \dot{~ i n ~ t h e ~ p l o t, ~ a l t h o u g h ~ w h a t ~ i t ~ i s ~ f o r ~ t h i s ~}$ $\mu \varepsilon \tau \alpha \beta \delta \lambda \eta$ to be a recognition is different from what it is for it to be a reversal.

One might object: if a recognition is finest when it is one in number with a reversal, why does Aristotle say that a recognition is finest

${ }^{28}$ Acknowledging this problem, Else (1957) is forced to take the "other recognitions" to be recognitions other than those defined at 1452a29-32 and to refer "in the way

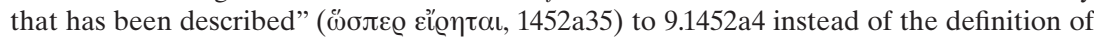

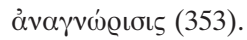

${ }^{29}$ Golden and Hardison $(1968,170-71)$ attempt to show that the finest recognitions (those that coincide with reversals) are just the recognitions of persons (cf. Rostagni 1945 ad 1452a38). But it is plain that Aristotle considers some recognitions of persons to be inferior. For example, he contrasts the swineherds' recognition of Odysseus through his scar (16.1454b25-30) with the nurse's recognition of Odysseus in the bath, which he says is "better" and '̇ं $\pi \varepsilon \varrho ı \pi \varepsilon \tau \varepsilon i \alpha \varsigma$ (1454b29). 
when it occurs at the same time as $(\check{\alpha} \mu \alpha)$ a reversal? But Aristotle is quite capable of saying that two processes that are one in number (though conceptually distinct) occur at the same time, as this passage from De Sensu shows:

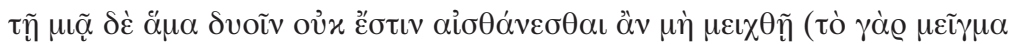

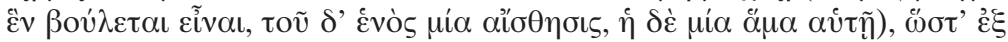

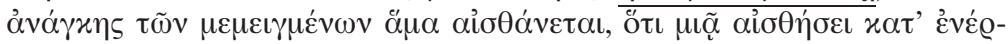

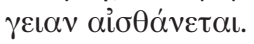

(De Sensu 7.447b9-13)

It is impossible to perceive two objects simultaneously in the same sensory act unless they have been mixed, for their amalgamation involves their becoming one, and the sensory act related to one object is itself one, and such an act, when one, is, of course, simultaneous with itself. Hence when things are mixed we of necessity perceive them simultaneously: for we perceive them by a perception actually one. (trans. Barnes)

Although when two perceptible qualities A and B are "mixed," the perception of $\mathrm{A}$ is one in number with the perception of $\mathrm{B}$, Aristotle is willing to say that the perception of A happens at the same time ( $\left.\check{\alpha}_{\mu} \alpha\right)$ as the perception of $\mathrm{B}$. Thus his claim that the finest recognition occurs at the same time as a reversal does not rule out the possibility I have been urging: that the recognition and the reversal are the very same $\mu \varepsilon \tau \alpha \beta 0 \lambda \eta$. It is notable that when Aristotle refers back to the finest recognition at 1452a37-38, he calls it a "recognition and reversal."

If the "finest recognitions" are recognitions that proceed from the construction of the plot, then the "other recognitions" must be the contrived recognitions that Aristotle discusses in chapter 16: for instance, those that depend on a fortuitously worn necklace (16.1455a20). What makes these recognitions inferior is that they do not come about as a necessary or likely consequence of the previous action of the play. Unlike the "best" and "finest" recognitions, they do not come about "from the incidents themselves" and accordingly are not one in number with reversals.

Both recognitions "in relation to inanimate and chance things" and recognitions of "whether or not someone has done [something]"

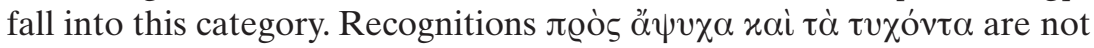
recognitions of inanimate objects, but recognitions by means of inanimate signs or tokens $(16.1454 \mathrm{~b} 20-30) .{ }^{30}$ It is because these signs are

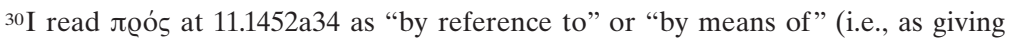
the "standard of judgement" through which the recognition is made, Smyth § 1695.3c). 


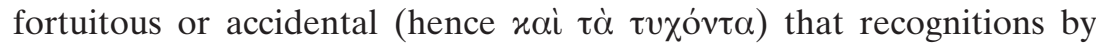
means of them fail to come about "from the incidents themselves" and thus fall short of the "best" recognitions.

As for recognitions of "whether or not someone has done [something]," it is clear that they are not meant to include cases like Oedipus' recognition that he killed his father and married his mother, since the recognition in Oedipus Tyrannus is of the "best" and "finest" kind (11.1452a33, 16.1455a18). Instead, I conjecture, Aristotle is referring to the recognitions he describes in chapter 16 as coming about by means of memory (1454b37-1455a4), like Alcinous' recognition of Odysseus in Odyssey 8 (71-95, 482-586). Seeing his guest weep as he listens to songs about Odysseus' exploits in Troy, Alcinous infers that he (or someone dear to him) is the man whose actions are being depicted in the song. Alcinous recognizes Odysseus, then, by recognizing that he has done something. Since Aristotle distinguishes such recognitions from the "best" recognitions, he must think that they do not proceed "from the construction of the plot." This explains why they do not coincide with reversals and hence fall short of the "finest recognitions."

To sum up: I have argued that when Aristotle defines reversal as a

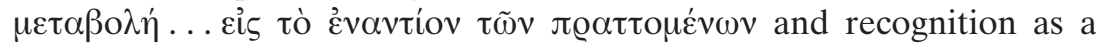

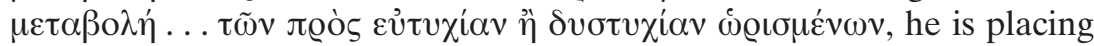
them in a common genus. Recognition and reversal are different kinds of $\mu \varepsilon \tau \alpha \beta 0 \lambda \eta$ in the characters' fortunes. But since their distinguishing features are not mutually exclusive, the same $\mu \varepsilon \tau \alpha \beta \beta_{\lambda} \eta$ can be both "from the very construction of the plot" and "from ignorance to knowledge, either into friendship or into enmity." Such a $\mu \varepsilon \tau \alpha \beta o \lambda \eta$ is both a recognition and a reversal: this is the kind of recognition Aristotle calls "finest." The "other" recognitions are $\mu \varepsilon \tau \alpha \beta$ o $\lambda \alpha i$ that are recognitions but not reversals, because they do not come about "from the very construction of the plot" but rely instead on contrived artifices (see figure 1).

By acknowledging the possibility that the same $\mu \varepsilon \tau \alpha \beta$ o $\lambda$ might be both a recognition and a reversal, then, we can explain Aristotle's ranking of recognitions as a corollary of his general preference for plots that unfold according to what is necessary and likely over "episodic" plots that proceed through ad hoc devices (9.1451b33-35). What has blinded interpreters to this possibility is the assumption that the $\mu \varepsilon \tau \alpha-$ ßo $\lambda \eta$ in knowledge and allegiance that is a recognition must be distinct from the $\mu \varepsilon \tau \alpha \beta \delta \lambda \eta \dot{~ o r ~ c h a n g e ~ o f ~ f o r t u n e ~ d e f i n e d ~ a t ~ t h e ~ e n d ~ o f ~ c h a p t e r ~} 7$. According to Else 1957, for instance, recognition is only a way "in 


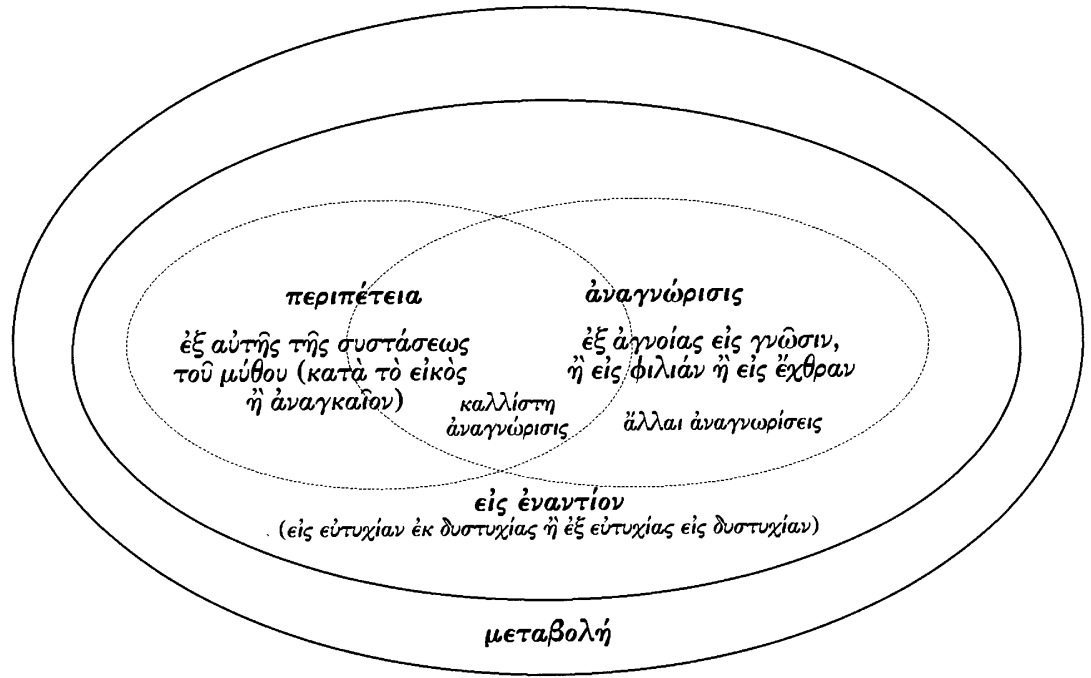

Figure 1.

which the tragic $\mu \varepsilon \tau \alpha \beta$ o $\lambda$ ' can be brought to a sharp focus"; "it is not in itself a $\mu \varepsilon \tau \alpha \beta \delta \lambda \eta$ of the action but only of the hero's awareness of what the action means" (355). Reversal, on the other hand, is a kind of tragic $\mu \varepsilon \tau \alpha \beta 0 \lambda \eta$ (344). Hence "although peripety and recognition can be thus associated, almost merged, they remain distinct moments and can appear separately" (354). If I am right about the proper construal of the definition of recognition, Else's distinction is unfounded. To say that recognition is one of the changes that have been defined by reference

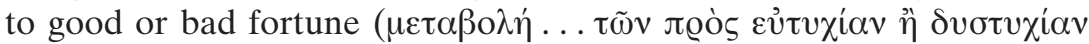
$\omega \varrho \iota \sigma \mu \varepsilon \dot{v}(\omega v)$ is precisely to say that it is a change in the fortunes of the protagonists-just like reversal. The exegetical fruitfulness of this hypothesis provides a further reason to endorse my construal of the definition. ${ }^{31}$

UNIVERSITY OF CALIFORNIA, BERKELEY

e-mail: jgm@uclink.berkeley.edu

${ }^{31}$ I am grateful to Myles Burnyeat, Mae Smethurst, and Eric Brown for their helpful comments. 


\section{BIBLIOGRAPHY}

Allan, D. J. 1976. "Peripeteia quid sit, Caesar occisus ostendit." Mnemosyne 29: 337-50.

Barnes, Jonathan, ed. 1984. The Complete Works of Aristotle. The Revised Oxford Translation. 2 vols. Princeton: Princeton University Press.

Belfiore, Elizabeth S. 1992. Tragic Pleasures: Aristotle on Plot and Emotion. Princeton: Princeton University Press.

Bonitz, H. 1870. Index Aristotelicus. 2d ed. Berlin: Royal Prussian Academy. (Reprinted Graz, 1955.)

Butcher, S. H. 1911. Aristotle's Theory of Poetry and Fine Art. 4th ed. New York. (Reprinted New York: Dover, 1951.)

Bywater, Ingram. 1909. Aristotle on the Art of Poetry. Oxford: Oxford University Press.

Cooper, Lane. 1947. Aristotle on the Art of Poetry. Rev. ed. Ithaca: Cornell University Press.

Dupont-Roc, Roselyne, and Jean Lallot. 1980. Aristote: La Poétique. Paris: Editions du Seuil.

Else, Gerald F. 1957. Aristotle's Poetics: The Argument. Cambridge: Harvard University Press. . 1967. Aristotle's Poetics. Ann Arbor: University of Michigan Press.

Fyfe, W. Hamilton. 1927. Aristotle, The Poetics; “Longinus," On the Sublime; Demetrius, On Style. Loeb Library. Cambridge: Harvard University Press.

Golden, Leon, and O. B. Hardison. 1968. Aristotle's Poetics: A Translation and Commentary for Students of Literature. Englewood Cliffs, N.J.: PrenticeHall.

Grube, G. M. A. 1958. Aristotle: On Poetry and Style. Indianapolis: BobbsMerrill.

Halliwell, Stephen. 1987. The Poetics of Aristotle. London: Duckworth.

- 1995. Aristotle: Poetics. (With Longinus: On the Sublime, trans. W. H. Fyfe, rev. Donald Russell; and Demetrius: On Style, trans. Doreen C. Innes.) Loeb Library. Cambridge: Harvard University Press.

Heath, Malcolm, trans. 1996. Aristotle: Poetics. London: Penguin.

Hubbard, M. E. 1972. Aristotle: Poetics. In Ancient Literary Criticism: The Principal Texts in New Translations, edited by D. A. Russell and M. Winterbottom. Oxford: Clarendon Press.

Janko, Richard, 1987. Aristotle Poetics I with the Tractatus Coislinianus, a Hypothetical Reconstruction of Poetics II, The Fragments of the On Poets. Indianapolis: Hackett.

Kamerbeek, W. J. 1965. “A Note on Arist. Poet. C. XI, 1452a22-26, 29-33.” Mnemosyne 18:279-81.

Kassel, Rudolfus. 1965. Aristotelis de Arte Poetica Liber. Oxford: Oxford University Press. 
Lucas, D. W. 1968. Aristotle: Poetics. Oxford: Oxford University Press.

Philippart, H. 1925. "La théorie aristotélicienne de l'anagnorisis." Revue des Etudes Grecques 38:171-204.

Potts, L. J. 1968. Aristotle on the Art of Fiction. Cambridge: Cambridge University Press.

Ross, W. D. 1924. Aristotle's Metaphysics: A Revised Text with Introduction and Commentary. 2 vols. Oxford: Clarendon Press.

1936. Aristotle's Physics. Oxford: Clarendon Press. 1955. Aristotle: Parva Naturalia. Oxford: Clarendon Press.

Rostagni, Augusto. 1945. Aristotele: Poetica. 2d ed. Turin.

Schrier, O. J. 1980. "A Simple View of Peripeteia." Mnemosyne 33:96-118.

Smyth, Herbert. [1920] 1956. Greek Grammar. Rev. ed. Cambridge: Harvard University Press.

Söffing, Werner. 1981. Deskriptive und Normative Bestimmungen in der Poetik des Aristoteles. Amsterdam: Grüner.

Vahlen, Johannes. 1885. Aristotelis De Arte Poetica Liber. 3d ed. Leipzig. (Reprinted Hildesheim: Olms, 1964.) . 1914. Beiträge zu Aristoteles Poetik. Berlin and Leibzig: Teubner.

Warrington, John. 1963. Aristotle's Poetics; Demetrius on Style; Longinus on the Sublime. London: Dent. 